\section{Threat to black sea urchins}

SIR - Many sea urchins are dying in the Florida Keys, in Puerto Rico and possibly elsewhere. Information about the locations and extent of this problem is urgently needed to understand this major disturbance.

In 1981, masses of diadematid sea urchins throughout the Hawaiian islands died. The phenomenon was never

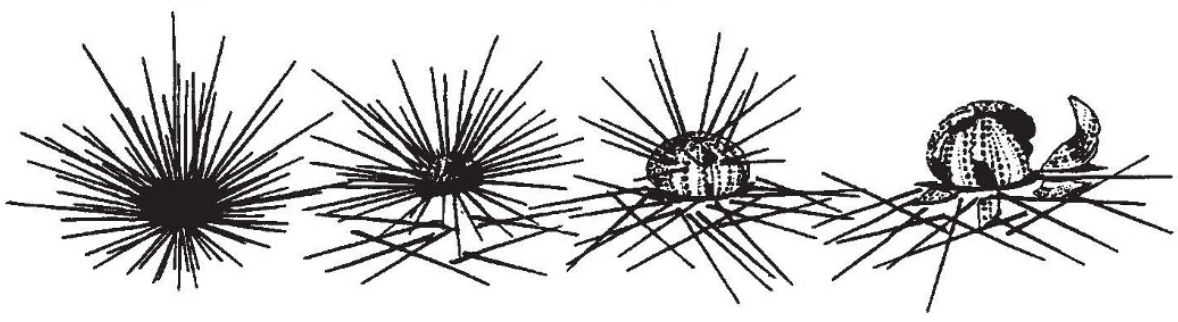

Stages in the death of a sea urchin.

studied $^{1}$. From early 1983 to the beginning of 1984, 95-99 per cent of all of the ecologically important black longspined sea urchins (Diadema antillarum) perished throughout the western North Atlantic, the largest and most devastating mortality of an invertebrate ever recorded ${ }^{2}$. New outbreaks of this disturbance occurred in Panama, St Croix and possibly other locations in the Caribbean in the autumn of $1985^{3}$.

In 1990, while coral reef bleaching was occurring in these areas ${ }^{4}$, we learned of mass mortalities of the urchins in Jamaica, the Cayman Islands and Belize. Each mortality of urchins occurred over a period of approximately one week, killing most of the remaining $D$. antillarum. We organized a working group to determine the cause of the deaths. Circumstantial evidence implicates an infectious pathogen ${ }^{2}$, possibly a virus ${ }^{5}$ or a bacterium.

Although we were unable to obtain moribund urchin specimens from the 1990 events, masses of urchins died at the beginning of May near Key West, Florida, mortalities spreading slowly up the Keys. We have obtained adequate specimens for microbial studies, but we need additional field observations of the disease signs, date of occurrence, locality, speed of progress of the disease, approximate numbers of animals affected, date on which last mortalities were seen, weather conditions, temperature, and so on.

Although our attention is focused on the Florida Keys, this disturbance may also be occurring in other areas of the

1. Birkeland, C. Echinoderm Studies 3, 1-79 (Balkema, Rotterdam, 1989).

2. Lessios, H. A., Robertson, D. R. \& Cublt. J. D. Science 226, 335-337 (1984)

3. Lessios, H. A. A. Rev. ecol. Syst. 19, 371-393 (1988). 4. Williams, E. H. Jr \& Bunkley-Williams, L. Atoll Res. Bull. 335, 1-73 (1980)

5. Williams, E. H. Jr \& Bunkley-Williams, L. Oceanus $30(4)$ 69-75 (1987).
Atlantic and among similar diadematids in the Pacific. A mass mortality of the commercially important West Indian sea egg (Tripneustes esculentus), for example, has just begun in Puerto Rico. If any readers can help, please send details to E.H.W.

The limited information available suggests that these new outbreaks are

progressing more slowly $(6-8$ days in a location, rather than $3-4$ days in $1983-84$ ), but they remain just as lethal to $D$. antillarum. It is to be hoped that cooperative efforts will demonstrate a cause for the disease and enable us to understand this ecological disturbance.

ERNEST H. WILLIAMS JR

Caribbean Aquatic Animal Health

Project,

Department of Marine Sciences,

University of Puerto Rico,

PO Box 908, Lajas,

Puerto Rico 00667-0980, USA

Telephone (809) 8992048

Fax (809) 8995500

Other signatories: Esther C. Peters, Jack Bauer, Grady Sullivan, Robert A. Bullis, Jeremy Woodley, Gina Ebanks, John M. Grizzle \& Kenneth E. Nusbaum. (Addresses available from E.H.W.)

\section{Lead risks}

SIR - Several US regulatory agencies are considering the health risks to children of low levels of lead in blood (less than $20 \mu \mathrm{g}$ per $100 \mathrm{ml}$ ). There is considerable debate about how to set acceptable levels. Bellinger, for example, has summarized ${ }^{1}$ several studies reporting data on IQ and lead in blood and teeth from several countries. The graphs in his paper have been widely circulated as key summaries of recent research. We are concerned, however, that the figures do not accurately represent the primary sources and thus may provide inappropriate policy guidelines.

Because lead exposure and IQ scores are both correlated with socioeconomic variables, these parameters have to be taken into account when estimating the effect of lead on IQ. But although Bellinger's Fig. 2 legend states that the data plotted are mean adjusted IQ scores, it is the raw, unadjusted data from ref. 2 which are in fact plotted. This is impor- tant because confounding bicovariates were found to account for half of the apparent effect. For Fig. 3, Bellinger bypassed the overall results in favour of plotting the raw data for one subgroup only. Similar distinctions apply to the data from refs 3-6 which are also plotted in the Bellinger figures.

We agree with Bellinger that the results from individual studies need to be put into a wider context. But it should be made clear, especially to policymakers, that the two summary graphs in ref. 1 cannot be used as the basis for regulatory decisions. Moreover, the actual lack of consistency across the studies suggests that the policy options being considered require further examination.

Milbank Memorial Fund,

SANFORD L. WEINER

Hazardous Substances Policy Review, 43 Madison Avenue,

Newton, Massachusetts 02160, USA

GAY GOODMAN

Gradient Corporation,

44 Brattle Street,

Cambridge,

Massachusetts 02138, USA

1. Bellinger, D. in Research in Infant Assessment (ed. Paul, N.) 73-97 (March of Dimes Birth Defects Foundation, White Plains, New York, 1989)

2. McMichael, A et al N Engl J. Med 319, 468 (1988).

3. Lansdown, R., Yule, W., Urbanowitz, M.-A. \& Hunter, J. Int. arch. Occup. Environ. Hth 57, 225-235 (1986)

4. Fulton. M. et al. Lancet I, 1221-1225 (1987).

5. Pocock, S., Ashby, D. \& Smith, M. int. J. Epidemiol. 16, 57-67 (1987).

6. Fergusson, D., Fergusson, D., Horwood, L. \& Kinzett, N. J. Child Psychol. Psychiat. 29, $793-809$ (1988)

\section{Refractive lens for X-ray focus}

SIR - The European Synchrotron Radiation Facility, the Advanced Photon Source in the United States and the Super Photon Ring in Japan will provide high-brilliance $\mathrm{X}$-rays with very long beam lines of up to $1 \mathrm{~km}$. To use the long beam line, we have designed a small-angle X-ray scattering camera, the small-angle resolution of which is as good as $10 \mu \mathrm{rad}$. We recognize the difficulty that the beam should be reduced to $1 \mathrm{~mm}$ in diameter and be focused at $1 \mathrm{~km}$ away from the light source. Conventional focusing devices such as totally reflecting mirrors require a stability of the order of $1 \mu \mathrm{rad}$ for the angle of reflection.

Here, we propose the use of refractive lenses which we believe have been overlooked for focusing X-rays ${ }^{1}$. The refractive index $n$ of materials for $\mathrm{X}$-rays is less than unity: $n=1-\delta ; \delta$ is of the order of $10^{-6}$ for an X-ray of $0.1 \mathrm{~nm}$ in wavelength, depending on the elements and density of the material ${ }^{2}$. Therefore, we can use a concave lens to focus $\mathrm{X}$-rays at long distances. The table 